\title{
Originals
}

\section{Studies on the insulin-antagonistic effect of catecholamines in normal man}

\author{
Evidence for the importance of $\boldsymbol{\beta}_{2}$-receptors
}

\author{
I. Lager ${ }^{1}$, S. Attvall ${ }^{1}$, B. M.Eriksson ${ }^{2}$, H. von Schenk ${ }^{3}$ and U.Smith ${ }^{1}$ \\ ${ }^{1}$ Department of Medicine II, Sahlgren's Hospital, Gothenburg, ${ }^{2}$ Research Department AB Hässle, Mölndal and ${ }^{3}$ Department of Clinical \\ Chemistry, University Hospital, Linköping, Sweden
}

\begin{abstract}
Summary. The insulin-antagonistic effect of adrenaline was studied in seven healthy subjects with the euglycaemic clamp technique using two insulin infusion rates $(40$ and $1200 \mathrm{mU}$. $\left.\left(\mathrm{m}^{2}\right)^{-1} \min ^{-1}\right)$. The adrenergic receptor mediating the adrenaline effect was characterized by concomitant infusion of propranolol $\left(\beta_{1}+\beta_{2}\right.$-antagonist) or metoprolol ( $\beta_{1}$-antagonist). Each subject was studied four times (placebo, adrenaline, adrenaline + propranolol, adrenaline + metoprolol). Glucose turnover was measured with $\mathrm{D}\left(3{ }^{3} \mathrm{H}\right)$-glucose. Similar plasma insulin levels were reached in all studies with the two insulin infusion rates (mean; placebo $51 \pm 3$ and $7421 \pm 337 \mathrm{mU} / 1$ respectively). Glucose production was completely inhibited by the low insulin level during placebo infusion. Adrenaline antagonized this effect so that a significant glucose production was seen at the low but not at the high insulin level. Propranolol, but not metoprolol, reversed this insulin-antagonistic ef-
\end{abstract}

fect of adrenaline. Glucose utilization increased from $2.53 \pm$ 0.17 to $7.28 \pm 0.88 \mathrm{mg} \cdot \mathrm{kg}^{-1} \cdot \mathrm{min}^{-1}$ during placebo when the insulin levels were increased from $4 \pm 0.3$ to $51 \pm 3 \mathrm{mU} / 1$. Increasing the insulin levels 150 -fold to $\sim 7500 \mathrm{mU} / 1$ only doubled the glucose utilization $\left(14.68 \pm 1.14 \mathrm{mg} \cdot \mathrm{kg}^{-1} \cdot \mathrm{min}^{-1}\right)$. Adrenaline induced a pronounced inhibition of glucose utilization at both insulin levels ( $78 \%$ and $37 \%$ inhibition respectively). Propranolol, but not metoprolol, prevented this effect of adrenaline. Thus, physiological adrenaline levels exert a pronounced insulin-antagonistic effect which is mediated by $\beta_{2}$-receptor stimulation. The inhibitory effect on glucose uptake is maintained even at high insulin levels when hepatic glucose production is completely abolished.

Key words: Adrenaline, insulin, glucose clamp, glucose production, glucose utilization, $\beta$-adrenoceptor blockade.
Hyperglycaemia is a frequent finding during various stressful conditions. The importance of catecholamines for the perturbed glucose tolerance is underlined by the ability of these hormones to impair insulin release [1,2] as well as to exert an effect on glucose turnover $[2,3]$. Further clinical support for the importance of catecholamines is offered by the high prevalence of diabetes in patients with a phaeochromocytoma [4]. The glucose levels in this condition are also normalized following the removal of the tumour [4]. Furthermore, the metabolic control deteriorates in diabetic patients during various stressful conditions such as infections, stroke and myocardial infarction [5]. The effect of catecholamines in raising the glucose levels is of major importance for the counter-regulatory action of these hormones during hypoglycaemia, particularly when the glucagon release is impaired [6]; this occurs frequently in Type 1 (insulin-dependent) diabetes [7, 8].

The insulin-antagonistic effect of catecholamines is due to both an increased hepatic glucose production and to a decreased peripheral utilization $[3,9]$. Although these effects are well-documented, little is known about the normal interaction between insulin and catecholamines in man as well as the type of adrenergic receptor mediating the insulin-antagonistic effect. Furthermore, it is not known if the catecholamines are equally effective in antagonizing the insulin action on hepatic glucose production and on peripheral glucose uptake.

The inhibitory effect of adrenaline on glucose utilization seems to be mediated by $\beta$-adrenoceptor stimulation [9]. Experimental studies with isolated fat cells in vitro have also shown that catecholamines, via $\beta$-stimulation, exert a marked inhibitory effect on the insulinstimulated glucose transport $[10,11]$. This effect seems to be due to both an inhibition of the insulin-induced translocation of the glucose transporters from the intracellular pool to the plasma membrane and to a reduced inherent activity of the glucose transporters [10, 11]. In addition, recent studies have shown that catecholamines, via $\beta$-stimulation, are capable of inducing a rapid reduction in insulin binding [12-14]. Thus, these studies have shown that catecholamines can rapidly 
$\left(\mathrm{t}^{1 / 2} \sim 2 \mathrm{~min}\right)$ induce a marked resistance to insulin through both receptor- and postreceptor-mediated perturbations [10-14]. The aim of the present study was to evaluate the insulin-antagonistic effect of adrenaline in normal man on both glucose production and utilization at different insulin level. To characterize the type of adrenergic receptor mediating these effects, experiments were performed with the $\beta$-receptor blocking agents propranolol ( $\beta_{1}+\beta_{2}$-antagonist $)$ and metoprolol ( $\beta_{1}$-antagonist).

\section{Subjects and methods}

\section{Subjects}

Seven healthy male subjects, aged 23-30 years, were studied. All subjects were of normal weight, had normal fasting glucose levels, and lacked a family history of diabetes. None of the subjects took any regular medication. The characteristics of the subjects are shown in Table 1. Informed consent was obtained from all subjects and the study was approved by the Ethical Committee of the University of Gothenburg, Sweden.

\section{Infusions}

All infusions were made through a Drum-Cartridge catheter placed in a cubital vein. Blood samples were collected from a catheter placed in the contralateral cubital vein. The arm was warmed with an electric pad to arterialize the venous blood. Insulin (Actrapid, Novo, Copenhagen, Denmark) was infused at a concentration of $0.6 \mathrm{IU} / \mathrm{ml}$ in isotonic saline with $4 \mathrm{mg} / \mathrm{ml}$ albumin added to prevent glass adhesion. Glucose $(300 \mathrm{mg} / \mathrm{ml})$ containing potassium chloride $(40 \mathrm{mmol}$ per $500 \mathrm{ml}$ ) was infused at variable rates in the same catheter as the insulin. This procedure prevented the development of hypokalaemia in the subjects. To evaluate the effect of adrenaline on glucose metabolism and to characterize the type of adrenergic receptor mediating the adrenaline response, the subjects were infused in a randomized order with adrenaline (Adrenaline, ACO, Stockholm, Sweden) with ascorbic acid $(1.0 \mathrm{mg} / \mathrm{ml})$ added to prevent oxidation, dissolved in isotonic saline, at a rate of $0.05 \mu \mathrm{g} \cdot \mathrm{kg}^{-1}$; adrenaline combined with the nonselective $\beta$-adrenergic antagonist propranolol (Inderal, ICI, Manchester, UK) given as a $5-\mathrm{mg}$ bolus dose intravenously followed by a constant infusion of $80 \mu \mathrm{g} / \mathrm{min}$; and adrenaline combined with the relatively $\beta_{1}$-selective antagonist metoprolol (Seloken, Hässle, Gothenburg, Sweden) given at the same dose as propranolol. Rates of glucose appearance $(\mathrm{Ra})$ and disposal $(\mathrm{Rd})$ were determined by infusing D- $\left(3{ }^{3} \mathrm{H}\right)$-glucose (New England Nuclear, Boston, Mass, USA) dissolved in isotonic saline. A primed infusion of $15 \mu \mathrm{Ci}$ was given followed by a constant infusion of $10 \mu \mathrm{Ci} / \mathrm{h}$.

\section{Euglycaemic clamp}

The euglycaemic clamp was performed simultaneously with the measurements of glucose production and utilization. The clamps were performed after an overnight fast essentially according to De Fronzo et al. [15] as previously reported in detail [16].

Following constant infusion of $\mathrm{D}-\left(3{ }^{3} \mathrm{H}\right)$-glucose for $120 \mathrm{~min}$ to achieve isotopic equilibration, the insulin infusion was started with a primed infusion for $10 \mathrm{~min}$ followed by a constant infusion of $40 \mathrm{mU} \cdot\left(\mathrm{m}^{2}\right)^{-1} \cdot \mathrm{min}^{-1}$ for $120 \mathrm{~min}$. The insulin infusion rate was then increased to $1200 \mathrm{mU} \cdot\left(\mathrm{m}^{2}\right)^{-1} \cdot \mathrm{min}^{-1}$ for another $120 \mathrm{~min}$. Arterialized venous blood $\left(\mathrm{O}_{2}\right.$ saturation $\left.88 \%\right)$ was used to measure the blood glucose concentration every $90 \mathrm{~s}$ with an automatically operating glucose sensor (Gambro AB, Lund, Sweden) using the glucose oxidase technique. The rate of glucose infusion was adjusted to maintain the glucose concentration at euglycaemia $(4.5 \mathrm{mmol} / 1)$.
Each subject was studied four times with at least 3 weeks between each study. The studies were performed in a randomized order with the infusion of either isotonic saline alone (placebo), adrenaline, adrenaline plus propranolol or adrenaline plus metoprolol during the euglycaemic clamp period with two insulin infusion rates.

\section{Analytical procedures}

During the isotopic equilibration period of $120 \mathrm{~min}$ blood samples for the determination of blood glucose and specific activity were taken before (at zero time), after $90 \mathrm{~min}$ and henceforth every $10 \mathrm{~min}$, including the clamp periods. Blood glucose was determined with the glucose oxidase technique. Blood samples for the determination of specific activity of glucose, concentrations of free insulin, catecholamines, free fatty acids, propranolol and metoprolol were kept on ice and stored at $-20^{\circ} \mathrm{C}$ until analyzed. Measurements of the specific activity of glucose were performed on deproteinized plasma. The samples were counted in a liquid scintillation counter for $50 \mathrm{~min}$.

Samples for the determination of free insulin, catecholamines and free fatty acid levels were collected three times during the second hour of each clamp period, and samples for the determination of the propranolol and metoprolol concentrations were taken twice during the same time periods.

The free insulin levels were determined on the supernatant of polyethyleneglycol treated samples [17] with a radioimmunoassay technique using Phadeseph insulin-kit (Pharmacia, Uppsala, Sweden).

Free fatty acids were determined according to Trout et al. [18] and catecholamines by a liquid chromotographic method with electrochemical detection [19].

The levels of propranolol and metoprolol were determined with a gaschromatographic method [20].

\section{Calculations}

Under the experimental conditions used, the total glucose turnover for a given period of time could be calculated by adding the mean rate of the calculated endogenous glucose production during that period to the amount of glucose infused during the same period. As glucose utilization reached steady-state during the second hour of each clamp period (180-240 and $300-360 \mathrm{~min}$ ), the glucose uptake during this period was used in the calculations. As the endogenous glucose production was completely inhibited during the high insulin infusion rate rate $\left(1200 \mathrm{mU} \cdot\left(\mathrm{m}^{2}\right)^{-2} \cdot \mathrm{min}^{-1}\right)$, the total glucose disposal during this period is equal to the mean glucose infusion rate during the same period. The reported levels of free insulin, free fatty acids and catecholamines during the clamp are the mean values during the second hour of each clamp period (180-240 and 300-360 min). The rates of glucose production $(\mathrm{Ra})$ and glucose utilization $(\mathrm{Rd})$ were determined by the method of primed constant tracer infusion [21]. This method assumes that rapid changes in the specific activity and concentration of glucose do not occur uniformly within the entire glucose pool. To compensate for non-uniform mixing, the non-steady state term of the equation was multiplied by a correction factor (pool-fraction) of 0.65 $[22,23]$. A sliding fit technique employing three consecutive values of glucose concentration and specific activity was used in the calculation [24].

\section{Statistical analyses}

Data are shown as means \pm SEM. Statistical differences between the groups were calculated with analysis of variance.

\section{Results}

\section{Catecholamine levels}

The basal adrenaline levels were similar before the infusions (placebo $0.14 \pm 0.02$; adrenaline $0.20 \pm 0.04$; adrenaline + propranolol $0.15 \pm 0.02$; adrenaline + met- 
oprolol $0.20 \pm 0.06 \mathrm{nmol} / 1)$. There was no significant increase in the adrenaline levels during the glucose clamps combined with saline infusion at either insulin infusion rate (Table 2). The adrenaline infusion produced high but physiological plasma levels, and steadystate was reached during both insulin infusion rates $(3.30 \pm 0.26$ and $3.72 \pm 0.27 \mathrm{nmol} / 1$ respectively). When the adrenaline infusion was combined with propranolol, significantly higher levels were seen during the clamp with the low insulin infusion rate $(6.08 \pm 0.43$ $\mathrm{nmol} / 1 ; p<0.001)$. However, this effect of propranolol was not seen in the presence of high insulin levels (Table 2). The combined infusion of adrenaline and metoprolol produced adrenaline levels which were higher than adrenaline infusion alone but lower than adrenaline + propranolol.

The noradrenaline levels were similar before the infusions (placebo $0.74 \pm 0.13$; adrenaline $0.72 \pm 0.11$; adrenaline + propranolol $0.74 \pm 0.05$; adrenaline + met-

Table 1. Characteristics of the subjects studied

\begin{tabular}{lccc}
\hline Sex & $\begin{array}{l}\text { Age } \\
\text { (years) }\end{array}$ & \multicolumn{1}{c}{$\begin{array}{l}\text { Height } \\
(\mathrm{cm})\end{array}$} & \multicolumn{1}{c}{$\begin{array}{l}\text { Weight } \\
(\mathrm{kg})\end{array}$} \\
\hline M & 23 & 192 & 78 \\
M & 25 & 193 & 85 \\
M & 26 & 187 & 78 \\
M & 27 & 182 & 75 \\
M & 27 & 174 & 66 \\
M & 29 & 177 & 71 \\
M & 30 & 189 & 80 \\
Mean \pm SEM & $27 \pm 1$ & $185 \pm 3$ & $76 \pm 2$ \\
\hline
\end{tabular}

oprolol $0.73 \pm 0.08 \mathrm{nmol} / 1)$. During placebo infusion there was no increase in noradrenaline levels during the euglycaemic clamps at either infusion rate (Table 2). Infusion of adrenaline, however, caused a significant elevation of the noradrenaline levels at both insulin infusion rates $(0.95 \pm 0.12$ and $0.99 \pm 0.15 \mathrm{nmol} / 1$ respectively; $p<0.02$ ). This effect was completely prevented by propranolol, when the noradrenaline levels were actually lower than during saline infusion $(0.57 \pm 0.05 \mathrm{nmol} / 1$; $p<0.02$ ). The noradrenaline levels remained unchanged when the adrenaline infusion was combined with metoprolol (Table 2).

\section{Propranolol and metoprolol levels}

The propranolol and metoprolol concentrations were similar and tended to increase during the clamp with the high insulin infusion rate (Table 2).

\section{Glucose levels}

The glucose concentration during the clamps was similar in all studies: placebo $4.5 \pm 0.3$; adrenaline $4.3 \pm 0.2$; adrenaline + propranolol $4.2 \pm 0.2$; adrenaline + metoprolol $4.3 \pm 0.1 \mathrm{mmol} / 1$ at both insulin infusion rates with coefficients of variation of $8.5 \pm 0.8 ; 9.3 \pm 1.1$; $9.6 \pm 1.3$ and $10.0 \pm 1.0 \%$ respectively.

\section{Insulin levels}

The fasting levels of free insulin were similar before each study: placebo $4 \pm 0.3$; adrenaline $4 \pm 0.5$; adrenaline + propranolol $4 \pm 0.5 ;$ adrenaline + metoprolol

Table 2. Steady state glucose infusion rate (SSGIR), glucose production (Ra), glucose utilization (Rd), plasma levels of hormones, fatty acids (FFA), propranolol and metoprolol before and during the euglycaemic clamps performed with two insulin infusion rates

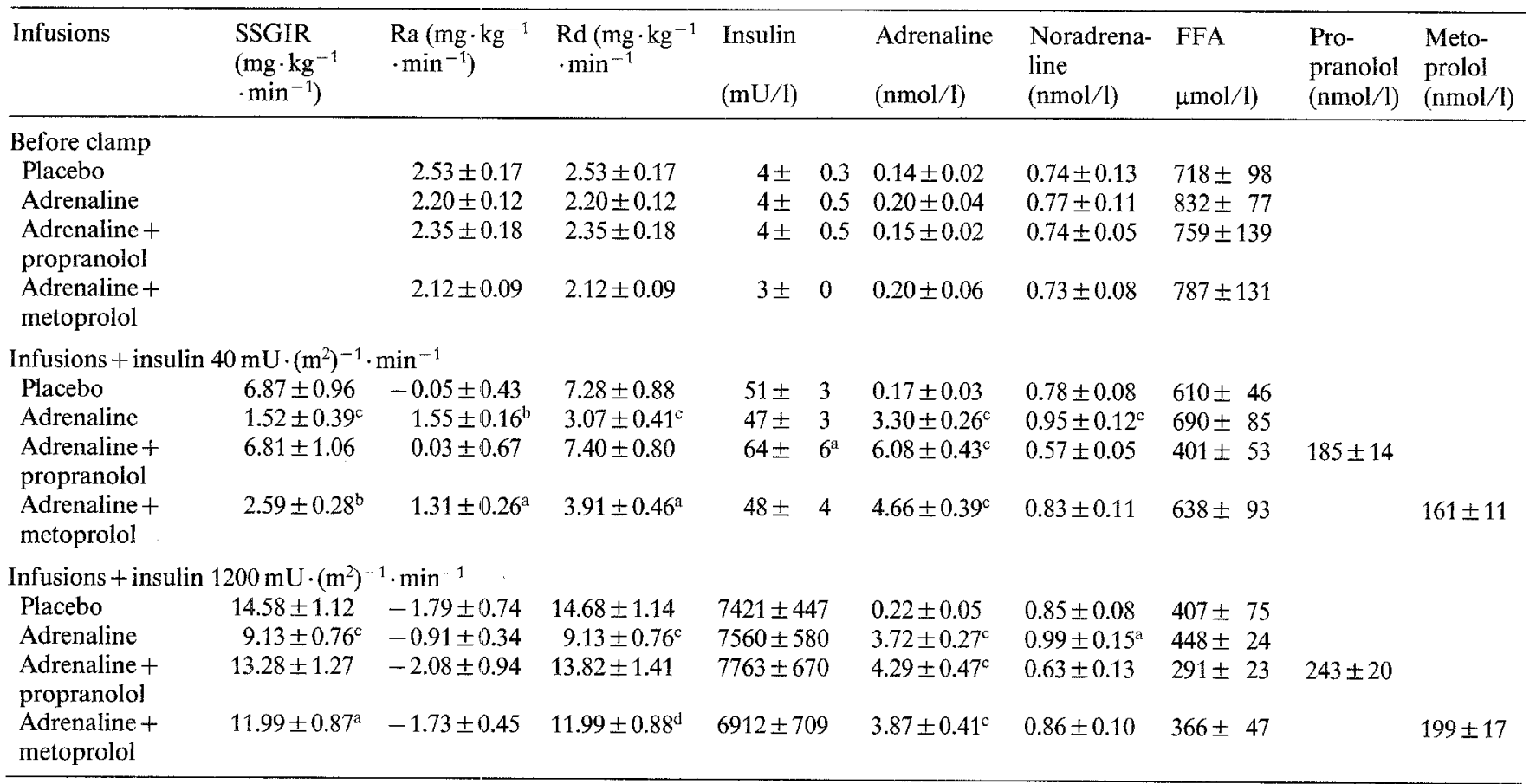

All values are means \pm SEM. The results shown were obtained during the last 60 min of each glucose clamp.

${ }^{\mathrm{a}} p<0.05 ;{ }^{\mathrm{b}} p<0.01 ;{ }^{\mathrm{c}} p<0.001 ;{ }^{\mathrm{d}} 0.10<p<0.05$ compared with the same time period during placebo 


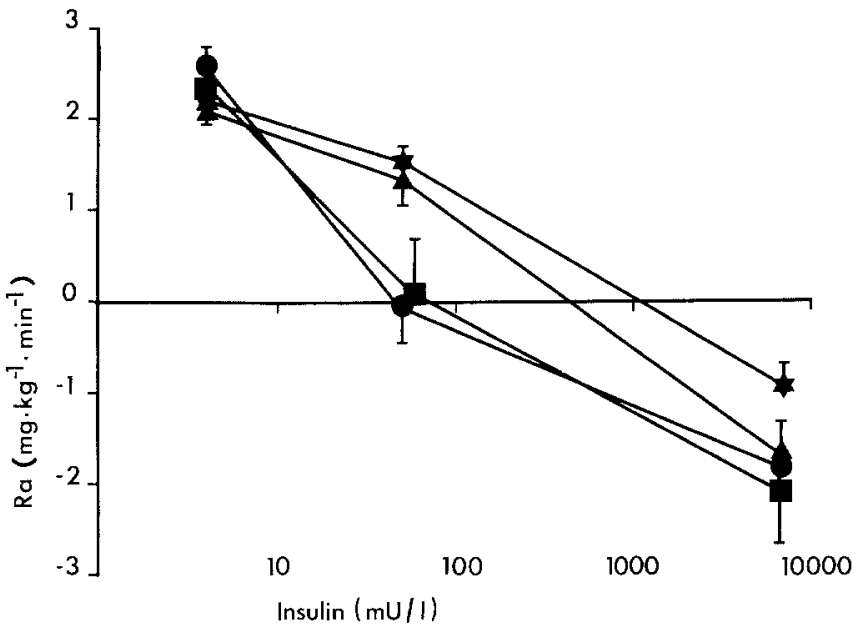

Fig. 1. Glucose production ( $\mathrm{Ra}$ ) before and during the euglycaemic glucose clamp performed with two insulin infusion rates (40 and $\left.1200 \mathrm{mU} \cdot\left(\mathrm{m}^{2}\right)^{-1} \cdot \mathrm{min}^{-1}\right)$. The clamps were either performed during saline infusion (placebo $\bullet$ ), infusion of adrenaline alone (*) or the combination of adrenaline + propranolol $(\boldsymbol{\square})$ or adrenaline + metoprolol $(\Delta)$

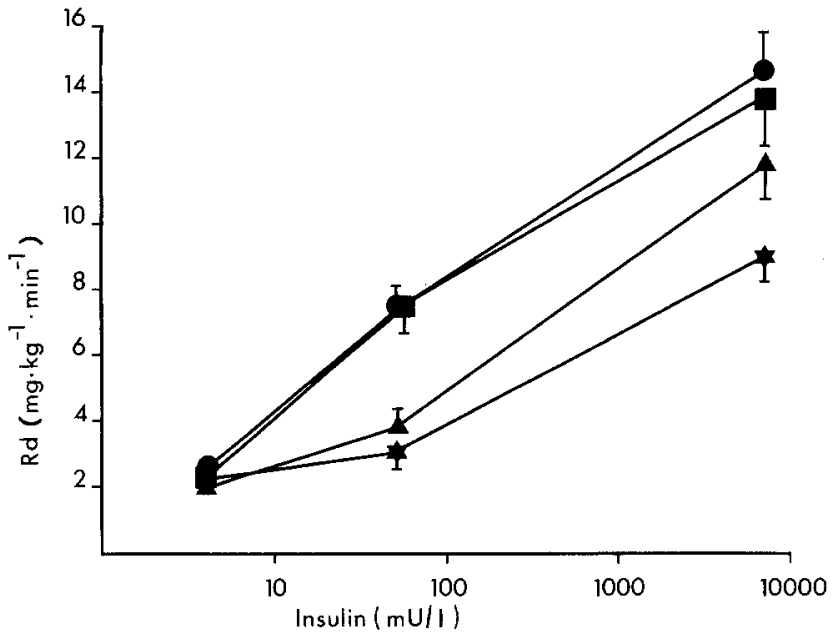

Fig. 2. Glucose utilization (Rd) before and during the euglycaemic glucose clamp with two insulin infusion rates $(40$ and $1200 \mathrm{mU}$. $\left.\left(\mathrm{m}^{2}\right)^{-1} \cdot \mathrm{min}^{-1}\right)$. Placebo $(\bullet)$, adrenaline $(\star)$, adrenaline + propranolol ( $\boldsymbol{\square})$, adrenaline + metoprolol ( $\mathbf{A})$

$3 \pm 0 \mathrm{mU} / 1$. During the second hour of euglycaemic clamp with the low insulin infusion rate $(40 \mathrm{mU}$. $\left.\left(\mathrm{m}^{2}\right)^{-1} \cdot \mathrm{min}^{-1}\right)$, steady-state levels of free insulin had been reached in all studies. Slightly higher insulin levels were seen during the adrenaline + propranolol infusion as compared to placebo $(p<0.05)$, whereas no difference was found between placebo and the other infusions (placebo $51 \pm 3$; adrenaline $47 \pm 3$; adrenaline + propranolol $64 \pm 6 ;$ adrenaline + metoprolol $48 \pm 4 \mathrm{mU} / 1)$. Infusion of insulin at a 30 times higher rate $\left(1200 \mathrm{mU}\left(\mathrm{m}^{2}\right)^{-1} \cdot \mathrm{min}^{-1}\right)$ resulted in free insulin levels that were about 150 times higher (Table 2). The free insulin levels increased during the second hour of the clamp with the high insulin infusion rate (mean in- crease $21 \%$ ) in all studies. There were, however, no significant differences between the groups (placebo $7421 \pm 447$; adrenaline $7560 \pm 580$; adrenaline + propranolol $7763 \pm 670$; adrenaline + metoprolol $6913 \pm$ $709 \mathrm{mU} / 1)$.

\section{Steady state glucose infusion rate}

During the second hour of the low insulin clamp, the steady state glucose infusion rate was significantly $(p<$ $0.001)$ lower during adrenaline infusion as compared to placebo (Table 2). This effect of adrenaline was completely reversed by propranolol but not by metoprolol (Table 2). A similar but less pronounced inhibitory effect of adrenaline was seen during the high insulin clamp $(p<0.01)$. This effect was also completely overcome by propranolol but not by metoprolol (Table 2 ). The insulin-antagonistic effect of adrenaline was maintained unchanged throughout the $2 \mathrm{~h}$ clamp at each insulin concentration as evaluated by the steady state glucose infusion rates (reduction of glucose infusion rate by adrenaline compared to placebo with insulin $40 \mathrm{mU} \cdot\left(\mathrm{m}^{2}\right)^{-1} \cdot \mathrm{min}^{-1}: 0-60 \mathrm{~min} 68 \pm 6 ; 60-120 \mathrm{~min}$ $78 \pm 5 \%$; with insulin $1200 \mathrm{mU} \cdot\left(\mathrm{m}^{2}\right)^{-1} \cdot \mathrm{min}^{-1} 0-60 \mathrm{~min}$ $42 \pm 3,60-120 \min 37 \pm 5 \%, p>0.10)$.

\section{Glucose production}

Under steady-state conditions, glucose production $(\mathrm{Ra})$ is equal to glucose utilization ( $\mathrm{Rd})$, and no difference was found between the groups before the infusions were started (placebo $2.53 \pm 0.17$; adrenaline $2.20 \pm$ 0.12 ; adrenaline + propranolol $2.35 \pm 0.18$; adrenaline + metoprolol $2.12 \pm 0.09 \mathrm{mg} \cdot \mathrm{kg}^{-1} \cdot \mathrm{min}^{-1}$ ).

Infusion of insulin completely inhibited the endogenous glucose production in the placebo group. This was the case even for the low insulin infusion rate (Fig.1, Table 2). In the presence of adrenaline, however, the same level of insulin only partly suppressed the glucose production $\left(1.55 \pm 0.10 \mathrm{mg} \cdot \mathrm{kg}^{-1} \cdot \mathrm{min}^{-1}\right)$. Propranolol, but not metoprolol, was able to completely overcome the effect of adrenaline on glucose production at the low insulin infusion rate (Fig. 1).

The high insulin infusion rate completely inhibited glucose production also in the presence of adrenaline (Table 2). In fact, the calculated Ra values were negative at these high insulin levels and there was no significant difference between the groups (Table 2).

\section{Glucose utilization}

In the absence of adrenaline, glucose utilization increased about 3 times during the low insulin infusion rate (from $2.53 \pm 0.17$ to $7.28 \pm 0.88 \mathrm{mg} \cdot \mathrm{kg}^{-1} \cdot \mathrm{min}^{-1}$ ) (Fig. 2). A further 150-fold increase of the insulin levels only doubled the glucose utilization (to 14.68 \pm $\left.1.14 \mathrm{mg} \cdot \mathrm{kg}^{-1} \cdot \mathrm{min}^{-1}\right)$. Adrenaline caused a marked inhibition of the glucose utilization both at the low $(78 \%$ 


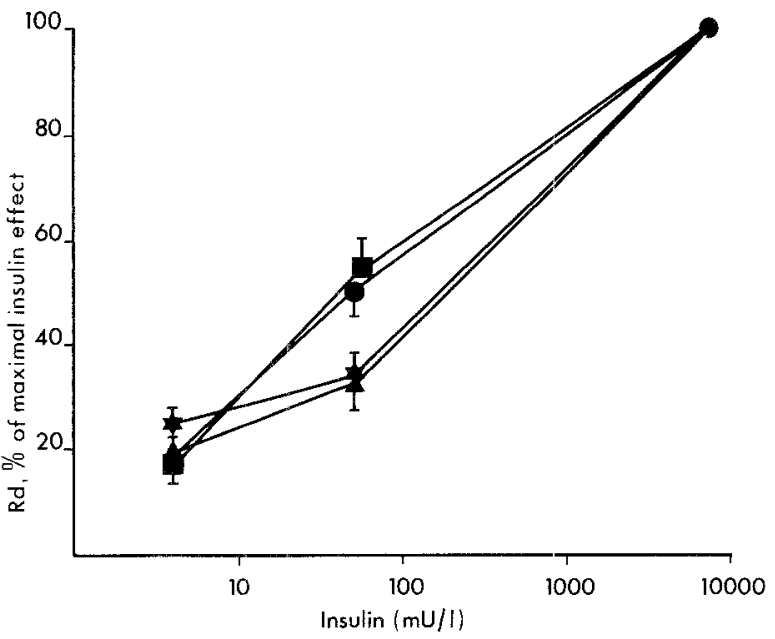

Fig.3. Glucose utilization (Rd) plotted as percent of the individual maximal insulin effect $(=100 \%)$. Insulin infusion 40 and $1200 \mathrm{mU}$. $\left(\mathrm{m}^{2}\right)^{-1} \cdot \mathrm{min}^{-1}$. Placebo $(\bullet)$, adrenaline $(*)$, adrenaline + propranolol (a), adrenaline + metoprolol ( $\mathbf{\Delta}$ )

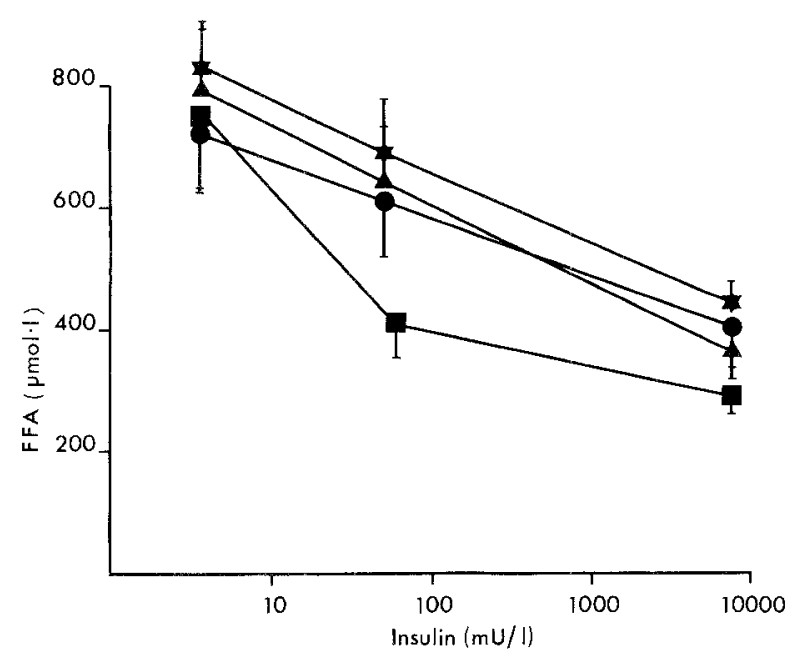

Fig. 4. Plasma levels of free fatty acids before and during the euglycaemic clamp with two insulin infusion rates (40 and $1200 \mathrm{mU}$. $\left.\left(\mathrm{m}^{2}\right)^{-1} \cdot \min ^{-1}\right)$. Placebo $(\bullet)$, adrenaline $(*)$, adrenaline + propranolol ( $)$, adrenaline + metoprolol ( $\mathbf{\Delta})$

inhibition) and at the high (37\% inhibition) insulin levels (Fig. 2). Infusion of propranolol prevented the inhibitory effect of adrenaline and this was particularly evident at the low insulin level (Table 2). Metoprolol, on the other hand, did not prevent the inhibitory effect of adrenaline on glucose utilization at the low insulin infusion rate but appeared more effective at high insulin levels (Fig. 2).

Thus, adrenaline markedly antagonized the effect of insulin on glucose utilization even in the presence of very high insulin concentrations. Propranolol, but not metoprolol, reversed the effect of adrenaline. To further analyse the effects, the individual glucose disposal rates were expressed as percent of the maximal rate for that that individual $(=100 \%)$. When the glucose disposal rates are expressed in this way, the responsiveness to in- sulin alone (placebo) and to adrenaline + propranolol is almost identical while the curves for both adrenaline and adrenaline + metoprolol are markedly shifted to the right (Fig. 3). From these data, the insulin concentration producing half-maximal effect on glucose disposal could be roughly estimated to about $40 \mathrm{mU} / 1$ for both placebo and adrenaline + propranolol and to about $200 \mathrm{mU} / 1$ for adrenaline and adrenaline + metoprolol.

\section{Free fatty acids}

The free fatty acid levels were similar before the infusions (placebo $718 \pm 98$; adrenaline $832 \pm 77$; adrenaline + propranolol $759 \pm 139$; adrenaline + metoprolol $787 \pm 131 \mu \mathrm{mol} / \mathrm{l}$ ). The levels also decreased with increasing insulin concentrations when adrenaline was infused alone or together with propranolol or metoprolol (Fig. 4 and Table 2).

\section{Heart rates}

The heart rates were similar before the infusions. An increase was seen in all subjects during the insulin and placebo infusion (from $64 \pm 2$ to $79 \pm 3$ beats/min during the high insulin infusion rate; $p<0.002$ ), even though the glucose levels were unchanged. The heart rates increased even further when adrenaline was infused during the clamps (from $65 \pm 5$ to $94 \pm 5$ beats/ min). This increase was prevented by the concomitant infusions of metoprolol or propranolol. In fact, in the presence of adrenaline + propranolol the heart rates were significantly lower than during placebo (from $62 \pm 3$ to $53 \pm 4$ beats $/ \mathrm{min} ; p<0.001)$.

\section{Discussion}

The present study clearly shows that infusion of adrenaline to high physiological blood levels markedly antagonizes the effect of insulin on glucose turnover. This effect is exerted through the stimulation of $\beta_{2}$-adrenergic receptors.

The adrenaline levels were higher when the catecholamine infusion was combined with propranolol, which is in agreement with previous results [25-27]. Higher levels were also seen in the presence of metoprolol, showing the importance of both $\beta_{1}$ - and $\beta_{2}$-adrenergic receptors for the clearance of adrenaline.

The noradrenaline levels decreased during the combined infusion of adrenaline and propranolol, probably due to a preponderant $\alpha_{2}$-receptor stimulation which leads to an inhibition of noradrenaline release [28]. Conversely, the higher noradrenaline levels seen with adrenaline alone are probably due to the stimulation of presynaptic facilitating $\beta_{2}$-receptors [28].

The insulin-antagonistic effect of adrenaline appears to be more pronounced for glucose utilization 
than for glucose production. This is supported by two observations. Firstly, the ability of adrenaline to stimulate the basal (preclamp) hepatic glucose production was prevented by the low insulin level while a marked inhibitory effect was seen on glucose disposal. Secondly, the inhibitory effect of adrenaline on glucose utilization remained even at very high insulin concentrations in contrast to the effect of adrenaline on glucose production. The physiological significance of this is, however, conjectural.

The complete inhibition of glucose production by a low insulin level $(51 \mathrm{mU} / \mathrm{l})$ in the absence of adrenaline is in agreement with the concept that hepatic glucose production is considerably more sensitive to insulin than glucose utilization $[29,30]$. The same insulin concentration only produced a half-maximal increase in glucose disposal.

The effect of catecholamines on glucose production in man has been suggested to be mediated by both $\alpha$ and $\beta$-adrenoceptor stimulation [25, 26, 31]. The $\alpha$-adrenergic effect seems to partially mediated through the inhibition of insulin release [25]. The present results show that $\beta$-antagonists alone can completely inhibit the direct effect of adrenaline on glucose production when insulin is held constant. This effect, then, appears to be mediated solely by $\beta$-receptor stimulation, which is in agreement with other recent suggestions $[9,32]$. In addition, the finding that the relatively $\beta_{1}$-selective drug, metoprolol, does not antagonize the effect of adrenaline shows the importance of $\beta_{2}$-receptors for catecholamine-stimulated glucose production in normal man. Under the current experimental conditions with euglycaemia and constant insulin levels, no evidence of a transient effect of adrenaline on glucose turnover was seen.

The half-maximal effect of insulin on glucose disposal was about $40 \mathrm{mU} / 1$, which is in agreement with another study in healthy subjects [29]. Under normal conditions a maximal effect of insulin is reached at about $700 \mathrm{mU} / 1$ [29]. Thus, the levels produced in the present study with the high insulin infusion rate $(\sim 7500 \mathrm{mU} / 1)$ should clearly exert a maximal effect on glucose utilization. Infusion of adrenaline at a rate sufficient to produce blood levels similar to those seen under normal stress situations, such as moderate hypoglycaemia [8], caused a marked impairment of the insulin-stimulated glucose uptake both at physiological and supraphysiological plasma insulin levels. Thus, it seems that both insulin sensitivity and responsiveness are decreased in the presence of elevated adrenaline levels. The insulin-antagonistic effect of adrenaline at low insulin levels also seems to be preferentially mediated through the $\beta_{2}$-adrenoceptors, since it was prevented by simultaneous infusion of propranolol but not by metoprolol. Metoprolol was able to partly overcome the antagonistic effect of adrenaline at high insulin levels. The reason for this discrepancy is unclear. However, it seems unlikely that different $\beta$-adrenoceptors should mediate the an- tagonistic effect of adrenaline at high and low insulin levels.

The $\beta$-antagonists propranolol and metoprolol are quipotent in reducing exercise-induced tachycardia, which is mainly a $\beta_{1}$-mediated effect, when given intravenously [33]. Similar plasma concentrations of the antagonists were also seen in the present study supporting the concept that an equal degree of $\beta_{1}$-blockade was reached.

The finding that mainly $\beta_{2}$-receptors mediate the antagonistic effect of catecholamines on insulin-stimulated glucose disposal provides an important explanation for the impairment in glucose recovery from hypoglycaemia seen with non-selective $\left(\beta_{1}+\beta_{2}\right)$ but not $\beta_{1}$-selective antagonists. We and others have previously reported that propranolol, but not metoprolol, impairs the recovery from hypoglycaemia in Type 1 diabetic patients [34-36]. Furthermore, propranolol has been reported to induce hypoglycaemia during prolonged physical exercise [37, 38]. This effect is probably also due to an impairment of the normal compensatory reduction of the peripheral glucose uptake [38].

The insulin-antagonistic effect of the catecholamine infusion, shown by both a shift in the dose-response curve and a reduced responsiveness, is identical to the insulin-antagonistic effects produced by catecholamines on fat cells in vitro. We and others [12-14] have recently shown that incubation with catecholamines leads to a rapid reduction in insulin binding via a $\beta$-adrenergic-dependent mechanism. The physiological importance of this finding is underlined by the recent observation that insulin binding to fat cells from patients with a phaeochromocytoma shows a negative correlation with the urinary catecholamine excretion [13]. Furthermore, catecholamines markedly inhibit the insulinstimulated glucose transport in rat fat cells provided that the ambient medium adenosine is degraded $[10,11]$. This effect seems, in part, to be due to an inhibition of the insulin-induced translocation of the glucose transporters from the intracellular pool to the plasma membrane as well as to a reduction of the inherent activity of the glucose transporters [10]. The cellular sensitivity to insulin is also markedly reduced since about 5-10 fold higher insulin concentrations are required for a halfmaximal response.

Elevated levels of free fatty acids reduce glucose uptake in peripheral tissues during moderate hyperinsulinaemia [39]. Thus, one potentially contributing factor to the insulin-antagonistic effect of adrenaline on glucose utilization could be a simultaneous elevation of the free fatty acids due to an increased lipolysis [40, 41]. As, however, the free fatty acids decreased during the clamp periods in all experiments, this explanation seems unlikely.

Increasing the insulin infusion rate 30 -fold (from 40 to $1200 \mathrm{mU} \cdot \mathrm{kg}^{-1} \cdot \mathrm{min}^{-1}$ ) caused about a 150 -fold increase in the free insulin levels. A lower insulin clearance during high infusion rates has also been found in 
other studies $[42,43]$ and is probably due to saturation of the insulin removal system.

The increased heart rate during the insulin infusion in the absence of a decreased glucose level may be due to a direct chronotropic effect of insulin $[44,45]$ or may be the result of the increased release of noradrenaline [46]. Since the noradrenaline levels were somewhat increased during the insulin infusion, our findings favour the latter hypothesis. The haemodynamic effects seen during the infusion of adrenaline with either $\beta$-blocking agent were the expected and similar to those recorded with the respective drug in connection with hypoglycaemia [34].

In conclusion, the present study shows that catecholamines, through the $\beta_{2}$-receptors, antagonize the effect of insulin on glucose production and disposal. The insulin-antagonistic effect of adrenaline on glucose production is overcome by high insulin concentrations, whereas the effect on glucose disposal persists. Thus, in the presence of insulin, catecholamines are important modulators of peripheral glucose uptake. This effect is, from a quantiative point of view, the most important for the insulin-antagonistic action.

Acknowledgements. The present study was supported by grants from Svenska Diabetes-förbundet, Nordisk Insulin fond and the Swedish Medical Research Council (project B 86-3506). The excellent help by U.Skredsvik, R. N., is gratefully acknowledged. Skillful secretarial assistance was given by G. Jonson and $\mathrm{H}$. Carlsten.

\section{References}

1. Robertson RP, Porte D (1973) Adrenergic modulation of basal insulin secretion in man. Diabetes 22: 1-8

2. Clutter WE, Bier DM, Shah SD, Cryer PE (1980) Epinephrine plasma metabolic clearance rates and physiologic thresholds for metabolic and hemodynamic actions in man. J Clin Invest 66: 94-101

3. Saccá L, Vigorito C, Cicala M, Corso G, Sherwin RS (1983) Role of gluconeogenesis in epinephrine-stimulated hepatic glucose production in humans. Am J Physiol 245: E294-302

4. Stenström G, Sjöström L, Smith U (1984) Diabetes mellitus in phaeochromocytoma. Acta Endocrinol 106: 511-515

5. Oswald GA, Corcoran S, Yudkin JS (1984) Prevalence and risks of hyperglycaemia and undiagnosed diabetes in patients with acute myocardial infarction. Lancet 1: 1264-1267

6. Rizza RA, Cryer PE, Gerich JE (1979) Role of glucagon, catecholamines, and growth hormone in human glucose counterregulation. J Clin Invest 64: 62-71

7. Bolli G, De Feo P, Compagnucci P, Cartechini MG, Angeletti G, Santeusanio F, Brunetti P, Gerich JE (1983) Abnormal glucose counter-regulation in insulin-dependent diabetes mellitus. Diabetes 32: 134-141

8. Lager I, von Schenk H, Smith U (1984) Improved but not normalized glucose counter-regulation during glucagon infusion in type 1 (insulin-dependent) diabetes. Diabetologia 26: 337-342

9. Deibert DC, DeFronzo RA (1980) Epinephrine-induced insulin resistance in man. J Clin Invest 65: 717-721

10. Smith U, Kuroda M, Simpson IA (1984) Counter-regulation of insulin-stimulated glucose transport by catecholamines in the isolated rat adipose cell. J Biol Chem 259: 8758-8763

11. Kashiwagi A, Huecksteadt TP, Foley JE (1983) The regulation of glucose transport by cAMP stimulators via different mechanisms in rat and human adipocytes. J Biol Chem 258: 13685-13692
12. Pessin JE, Gitomer W, Yoshitomo O, Oppenheimer CL, Czech M (1983) $\beta$-adrenergic regulation of insulin and epidermal growth factor receptors in rat adipocytes. J Biol Chem 258: 7386-7394

13. Lönnroth P, Wesslau C, Stenström G, Tisell LE, Smith U (1985) Reduced insulin binding to human fat cells following beta-adrenergic stimulation - experimental evidence and studies in patients with a phaeochromocytoma. Diabetologia 28: 901-906

14. Lönnroth P, Smith U (1983) Beta-adrenergic dependent down-regulation of insulin binding in rat adipocytes. Biochem Biophys Res Commun 112: 972-979

15. DeFronzo RA, Tobin JD, Andres R (1979) Glucose clamp technique: a method for quantifying insulin secretion and resistance. Am J Physiol 237: E214-223

16. Lager I, Lönnroth P, von Schenk H, Smith U (1983) Reversal of insulin resistance in type I diabetes after treatment with continuous subcutaneous insulin infusion. Br Med J 287: 1661-1664

17. Kuzuya H, Blix PM, Horwitz DL, Steiner DF, Rubenstein AH (1979) Determination of free and total insulin and C-peptide in insulin-treated diabetics. Diabetes 26:22-29

18. Trout DL, Estes EH, Friedberg SJ (1960) Titration of free fatty acids of plasma: a study of current methods and a new modification. J Lipid Res 1: 199-201

19. Eriksson B-M, Persson B-A (1982) Determination of catecholamines in rat heart tissue and plasma samples by liquid chromatography with electrochemical detection. J Chromatography 228: 143-154

20. Ervik M (1975) Quantitative determination of metoprolol in plasma and urine by gas chromatography. Acta Pharmacol et Toxicol 36 (Suppl V): 136-144

21. De Bodo RCR, Steele N, Altszuler N, Dunn A, Bishop JS (1963) On the hormonal regulation of carbohydrate metabolism: Studies with $\mathrm{C}^{14}$-glucose. Recent Prog Horm Res 19: 445-488

22. Cowan JS, Hetenyi C (1971) Glucoregulatory responses in normal and diabetic dogs recorded by a new tracer method. Metabolism 20: $360-372$

23. Radziuk J, Norwich KH, Vranic M (1978) Experimental validation of measurements of glucose turnover in nonsteady state. Am J Physiol 234: E84-E93

24. Wajngot A, Roovete A, Vranic M, Luft R, Efendic S (1982) Insulin resistance and decreased insulin response to glucose in lean type 2 diabetics. Proc Natl Acad Sci USA 79: 4432-4436

25. Rizza RA, Haymond MW, Miles JM, Verdonk CA, Cryer PE, Gerich JE (1980) Effect of $\alpha$-adrenergic stimulation and its blockade on glucose turnover in man. Am J Physiol 238; E467-E 472

26. Shamoon $\mathrm{H}$, Sherwin $\mathrm{R}$ (1984) $\beta$-adrenergic blockade is more effective in suppressing adrenaline-induced glucose production in type I (insulin-dependent) diabetes. Diabetologia 26: 183-189

27. Cryer PE, Rizza RA, Haymond MW, Gerich JE (1980) Epinephrine and norepinephrine are cleared through beta-adrenergic but not alpha-adrenergic mechanisms in man. Metabolism 29: 1114-1118

28. Lefkowitz RJ, Caron MG, Stiles GL (1984) Mechanisms of membrane receptors regulation - biochemical, physiological and clinical insights derived from studies on the adrenergic receptors. $\mathrm{N}$ Engl J Med 310: 1570-1579

29. Rizza RA, Mandarino LJ, Gerich JE (1980) Dose-response characteristics for effects of insulin on production and utilization of glucose in man. Am J Physiol 240; E630-639

30. DeFronzo RA, Ferrannini E, Hendler R, Felig P, Wahren J (1983) Regulation of splanchnic and peripheral glucose uptake by insulin and hyperglycaemia in man. Diabetes $32: 35-45$

31. Exton JH (1980) Mechanisms involved in $\alpha$-adrenergic phenomena: role of calcium ions in actions of catecholamines in liver and other tissues. Am J Physiol 238: E3-E12

32. Rizza RA, Cryer PE, Haymond MW, Gerich JE (1980) Adrenergic mechanisms for the effects of epinephrine on glucose production and clearance in man. $J$ Clin Invest 65: 682-689

33. Johnsson G, Nyberg G, Sölvell L (1975) Influence of metoprolol and propranolol on hemodynamic effects induced by physical work and isoprenaline. Acta Pharmacol et Toxicol 36 (suppl V): $69-75$ 
34. Lager I, Blohmé G, Smith U (1979) Effect of cardioselective and non-selective $\beta$-blockade on the hypoglycaemic response in insulin-dependent diabetics. Lancet 1: 458-462

35. De Feo P, Bolli G, Perriello G, De Cosmo S, Compagnucci P, Angeletti G, Santeusanio F, Gerich JE, Motolese M, Brunetti P (1983) The adrenergic contribution to glucose counterregulation in type I diabetes mellitus. Diabetes 32:887-893

36. Kleinbaum J, Shamoon H (1984) Effect of propranolol on delayed glucose recovery after insulin-induced hypoglycaemia in normal and diabetic subjects. Diabetes Care 7:155-162

37. Lundborg P, Åström H, Bengtsson C, Fellenius E, von Schenck H, Svensson L, Smith U (1981) Effect of $\beta$-adrenoceptor blockade on exercise performance and metabolism. Clin Sci 61:299-305

38. Simonsson DC, Koivisto V, Sherwin RS, Ferrannini E, Hendler R, Juhlin-Dannfelt A, DeFronzo RA (1984) Adrenergic blockade alters glucose kinetics during exercise in insulin-dependent diabetics. J Clin Invest 73: 1648-1658

39. Ferrannini E, Barrett EJ, Bevilaqua S, DeFronzo RA (1983) Effect of fatty acids on glucose production and utilization in man. J Clin Invest $72: 1737-1747$

40. Smith U (1980) Adrenergic control of human adipose tissue lipolysis. (Editorial). Eur J Clin Invest 10: 343-344

41. Burns TW, Langley PE, Terry BE, Bylund DB, Hoffman BB, Tharp MD, Lefkowitz RJ, García-Saínz A, Fain JN (1981) Pharmacological characterizations of adrenergic receptors in human adipocytes. J Clin Invest 67:467-475
42. Rizza RA, Mandarino LJ, Gerich JE (1982) Cortisol-induced insulin resistance in man: Impaired suppression of glucose production and stimulation of glucose utilization due to a postreceptor defect of insulin action. J Clin Endocrinol Metabol 54: 131-138

43. Fink RO, Revers R, Kolterman OG, Olefsky JE (1985) The metabolic clearance of insulin and feedback inhibition of insulin secretion are altered with aging. Diabetes 34: 275-280

44. Lee JL, Downing SW (1976) Effects of insulin on cardiac muscle contraction and responsiveness. Am J Physiol 230: 1360-1365

45. Jacobsen F, Christensen NJ (1979) Stimulation of heart rate by insulin is influenced by $\beta$-adrenergic receptor blockade in rabbits. Scand J Clin Lab Invest 39: 253-256

46. Rowe JE, Young JB, Minaker ML, Stevens AL, Palotta J, Landsberg L (1981) Effect of insulin and glucose infusions on sympathetic nervous system activity in normal man. Diabetes 30 : $219-225$

Received: 18 November 1985

and in revised form: 12 May 1986

\section{Dr. Ulf Smith}

Department of Medicine II

Sahlgren's Hospital

S-41345 Gothenburg

Sweden 